\title{
Determination of the Optimal Condition of Direct Blue Dye Removal from Aqueous Solution Using Eggshell
}

\author{
RANA ABDULLAH ABBAS ${ }^{1}$, AHLAM ABDUL-RHEEM FARHAN², HUSSAM NADUM ABDALRAHEEM AL ANI', \\ AURELIA CRISTINA NECHIFOR ${ }^{3 *}$ \\ 1Department of Chemical Industrial, Institute of Technology/ Baghdad, Middle Technical University, Iraq \\ 2Department of Water Resources Techniques, Institute of Technology/ Baghdad, Middle Technical University, Iraq \\ 3Politehnica University of Bucharest, Faculty of Applied Chemistry and Material Science, Analytical Chemistry and Environmental \\ Engineering Department, 1-7 Gheorghe Polizu Str., 011061, Bucharest, Romania
}

\begin{abstract}
Eggshells was used as a natural adsorbent to remove direct blue(DB) dye from aqueous solution and investigating the four factors that affect the adsorption of $D B$ dye ; amount of eggshell rang $(0.1-1 \mathrm{~g})$, initial concentration (10 - $60 \mathrm{mg} / \mathrm{L}$ ), time ( 5 - $45 \mathrm{~min}$.) and pH (3-11). Central Composition Design with four variables and five levels coupled with response surface method was adopted to geta second order polynomial equation for dye removal percentage as the response, and to obtain the optimum conditions for maximum dye removal percentage ; which reach $84 \%$ with optimum point, eggshell $(0.835 \mathrm{~g})$, time (24min.) , initial dye concentration ( $10 \mathrm{mg} / \mathrm{L}$ ) , $\mathrm{pH}$ (4.2). The most effecting factors on dye removal are $\mathrm{pH}$ and initial dye concentration. Langmuir, Freundich model gives good fitting with $\left(R^{2}>0.98\right)$. The process of adsorption of $D B$ dye on eggshell fitted a pseudo-second order kinetic model.
\end{abstract}

Keywords: eggshells adsorbent, direct blue remove, second order polynomial equation, pseudo-second order kinetic model

Environmental pollution control has been a concerned issue in many countries; air and wastewater pollution are the most concerned environmental pollution [1].There are much than 100,000 different synthetic dyes parameter on the market, produced in over 700,000 tons annually worldwide[2] . Wastewater pollution gives bad effects on public water supplies which can cause health problems such as diarrhea [3]. Major pollutants in textile wastewater are high acidity, heat and other soluble substances main pollution in textile wastewater came from dyeing and finishing processes $[4,5]$. Many treatment processes included physical, chemical, and biological have been employed to treat various municipal and industrial wastewaters for example chemical, biological, food, peanut hulls, maize bran, and others [6-9]. Many researchers suggested that the potential exists for the use of highly concentrated sunlight in the removal of dyes from wastewater. Industrial facilities take clean water from nature and re-contaminated water into water sources where these industrial pollutants affect the physical properties of natural water such as the intensity, color and taste, etc., have attracted the attention of several investigations for the removal of dyes [10-12].

In this work, we reuse waste eggshells as a dye sorbent.
The model of Design Expert was used to determine the optimum condition for dye removal from polluted aqueous solution.

The effect of four parameters in adsorption of dye including: sorbent dosage (eggshell), time, initial dye concentration, $\mathrm{pH}$ values and their interactions on dye removal were investigated.

A central composite design, (CCD) was used to obtain statistical model for dye removal percentage and then finding optimal conditions for the effective factors by response surface methodology was confirmed by the analysis of variance (ANOVA).

\section{Experimental part}

Materials and methods

Preparation and characterization of eggshell powder

Egg shells were collected from house, to remove impurity, the shells washed with distilled water followed by solar dried and ground into powder by using. The powdered egg shells were sieved to obtain particles of various size ranges and dried at $105 \mathrm{C}^{\circ}$ in an oven for $2 \mathrm{~h}$. The particle sizes of $(250 \mathrm{\mu m})$ were taken for adsorption studies. The egg shell powder was stored in air tight container for further use. No other chemical treatment was used prior to adsorption experiments.

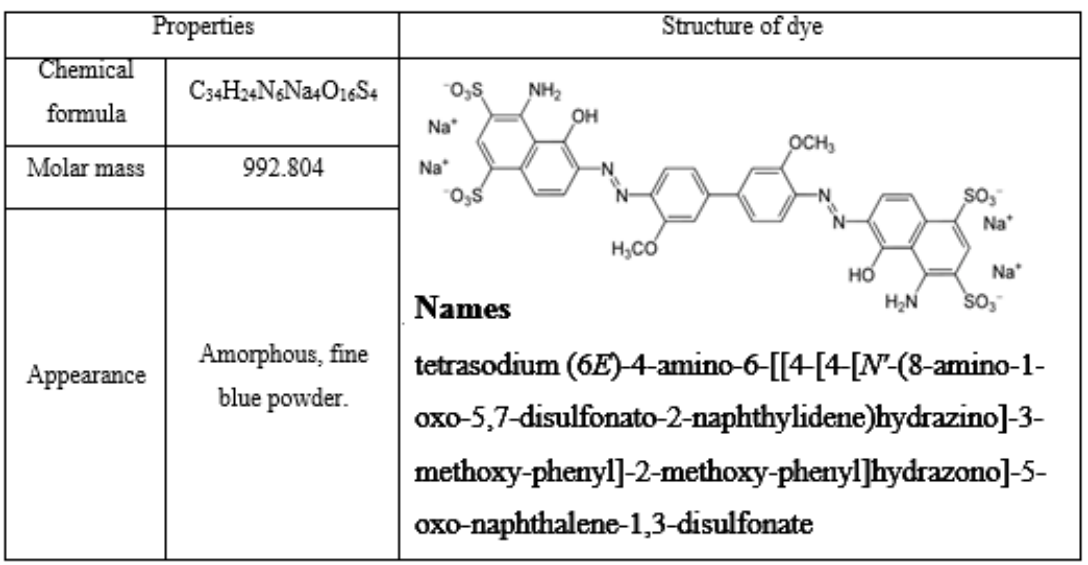

Table 1

THE CHEMICAL NAME AND PROPERTIES OF DIRECT BLUE DYE

\footnotetext{
* email: aureliacristinanechifor@gmail.com
} 
DirectBlue dye (DB): was used withoutfurther purification, (from textile factory in Baghdad) the properties of Direct Blue dye show in table (1). Direct Blue is an organic compound that is one of many azo dyes. It is used as a substantive dye for textiles with high contents of cellulose, i.e. cotton. It is prepared by the azo coupling of the amino naphthalene and diazotized derivative of 0 dianisidine [13].

\section{Dye solution preparation}

Dye solution was prepared by dissolving in volumetric flask an accurately weighted dye in distilled water at a concentration of $(10,22.5,35,47.5,60) \mathrm{mg} / \mathrm{L}$. Taking such concentrations of DB dye to determine the maximum absorbance wave length ( $\lambda \max )$ with absorbance spectrum rang (200-800 $\mathrm{nm}$ ) by using UV-visible spectrophotometer. The maximum absorbance $\left(\lambda_{\text {max }}\right)$ of DB solution was in the visible region at $566 \mathrm{~nm}$, then using this $\lambda$ max to prepare a calibration curve of absorbance and concentration of DB dye

\section{Batch mode adsorption studies}

The batch adsorption experiment were conducted in $250 \mathrm{~mL}$ capacity conical flask containing adsorbent (eggshell) (0.1-1) $\mathrm{g}$ and $50 \mathrm{~mL}$ of DB solution at various initial concentrations and agitated at $150 \mathrm{rpm}$ in water bath shaker at predetermined time intervals (5-45) min at $24^{\circ} \mathrm{C}$.

Dilute $(0.1 \%) \mathrm{HCl}$ or $(0.1 \%) \mathrm{NaOH}$ was used for $\mathrm{pH}$ adjustment in order not to increase the volume of samples too much and keep the error created by $\mathrm{pH}$ adjustment in a reasonable range. The adsorbate solution was centrifuge at $(3000 \mathrm{rpm})$ and for ( $15 \mathrm{~min}$.). The residual concentration of the sample is measured by spectrophotometric at $\lambda=$ $566 \mathrm{~nm}$.

\section{Equilibrium studies}

Equilibrium data were obtained by adding $0.775 \mathrm{~g}$ of eggshell into a series of Erlenmeyer flasks each filled with $50 \mathrm{~mL}$ of dye solution. the initial dye concentration ranges from $10-60 \mathrm{mg} / \mathrm{L}$ then placed in water bath shaker for 90 min (take as equilibrium time) at $24^{\circ} \mathrm{C}$ and $\mathrm{pH} 5$ 15].

The dye removal percentage was calculated from [14-

$$
\mathrm{R}_{\mathrm{e}} \%=100 \quad\left(\mathrm{C}_{0}-\mathrm{C}_{\mathrm{e}}\right) / \mathrm{C}_{0}
$$

where: $C_{0}$ and $C_{e}$ are the initial and the equilibrium concentrations ( $\mathrm{mg} / \mathrm{L}$ ) of Direct Blue in solution, respectively, $R_{e} \%$ percentage of dye removal at time of equilibrium.

The amount of sorption per gram of eggshell at time of equilibrium $\mathrm{q}_{\mathrm{e}}$ and at any time $\mathrm{t}, \mathrm{q}_{\mathrm{t}}(\mathrm{mg} / \mathrm{g})$ was calculated from

$$
\begin{aligned}
& q_{e}=\left(C_{0}-C_{f}\right) 5 \varnothing \tilde{N} Y(V / m) \\
& q_{t}=\left(C_{0}^{0}-C_{t}\right) 5 \varnothing N Y Y(V / m)
\end{aligned}
$$

$\mathrm{C}_{t}$ : dye concentration at any time, $\mathrm{m}(\mathrm{g})$ : weight of egg shells, and $V(L)$, the solution of volume taken for experiment] 15].

\section{Sorption kinetic}

Contacting a volume of $50 \mathrm{~mL}$ of solution at 10 and 22.5 $\mathrm{mg} / \mathrm{L}$ of dye at interval of definite time, using $0.775 \mathrm{~g}$ of eggshell at $24^{\circ} \mathrm{C}$ and $\mathrm{pH} 5$.

\section{Design of experiments}

To obtain the largest amount of information from a small number of experiments we are using central composite design method (CCD). In this study four variables (factors) including sorbent dosage (Egg shell), contact time, initial dye concentration and $\mathrm{pH}$. Each variable have 5 levels. These values were designated by the codes $(-2,-1,0,1,2)$ and are given in table ( 2 ). The percentage of dye removal for each experiment was calculated from eq. (4), which was spotted as the response.

$$
R_{t} \%=100\left(C_{0}-C_{t}\right) / C_{0}
$$

where: $R_{t} \%$ percentage of dye removal at any time.

According to experimental design of the four variables there was thirty one experiments. The model of design was the second-order polynomial response equation was used to make relation between the collected response and variables as in eq. (5) [16]:

$$
\begin{gathered}
Y=b_{0}+b_{1} X_{1}+b_{2} X_{2}+b_{3} X_{3}+b_{4} X_{4}+b_{12} X_{1} X_{2}+b_{13} X_{1} X_{3} \\
+b_{14} X_{1} X_{4}+b_{23} X_{2} X_{3}+b_{24} X_{2} X_{4}+b_{34} X_{3} X_{4}+b_{11} X_{1}^{2}+b_{22} X_{2}^{2} \\
+b_{33} X_{3}^{2}+b_{44} X_{4}^{2}
\end{gathered}
$$

where: $Y$ is the predicted response (dye removal \%). ( $b_{\alpha}$ $\left.b_{1}, b_{2}, b_{2}, b_{4} \ldots\right)$ are regression coefficients. $\left(X_{1^{\prime}}, X_{2}, X_{3^{\prime}}, X_{4}\right)^{q}$ are coded levels of the variables.

By using the Multi -Variable Least Squares to fitted the experimental data and estimate regression coefficients in the eq. (5).

Table 2

RANG OF CODED AND THEIR REAL EXPERIMENTAL VALUES OF VARIABLES USED IN THE CENTRAL COMPOSITE DESIGN

\begin{tabular}{|c|c|c|c|c|}
\hline $\begin{array}{c}\text { Coded } \\
\text { Level }\end{array}$ & $\begin{array}{c}\text { Eggshell (g) } \\
\mathrm{X}_{1}\end{array}$ & $\begin{array}{c}\text { Time (min) } \\
\mathrm{X}_{2}\end{array}$ & $\begin{array}{c}\text { Dye con. } \\
(\mathrm{mg} / \mathrm{L}) \\
\mathrm{X}_{3}\end{array}$ & $\begin{array}{c}p \mathrm{H} \\
\mathrm{X}_{4}\end{array}$ \\
\hline-2 & 0.1 & 5 & 10 & 3 \\
\hline-1 & 0.3250 & 15 & 22.5 & 5 \\
\hline 0 & 0.55 & 25 & 35 & 7 \\
\hline 1 & 0.775 & 35 & 47.5 & 9 \\
\hline 2 & 1 & 45 & 60 & 11 \\
\hline
\end{tabular}

\section{Results and discussions}

\section{Response surface of dye removal}

The experimental design results of dye removal \% is given in table (3) includes 31 runs, real data obtained from experiments and the fitted values of the developed model. These results were subjected to analysis of variance (ANOVA); in table (4) shows the regression coefficients for the response function (removal \% of dye) and P-value lower than 0.05 was considered significant in surface response analysis. The $p$-value of the coefficient for linear effect of the factors : contact time, initial dye concentration and $p \mathrm{H}$ are less than 0.05; so for the response is significant except for amount of eggshell (absorbent) $(P=0.144$ ) is less significant, and the interaction effect of the variables as show in table (4) some of it significant other nonsignificant depending on $\mathrm{P}$-value.

In table (4) the $R^{2}$ values ( $R^{2}, R^{2}$ (prediction), $R^{2}$ (adjusted)) shows no large difference this means good fit to the model. So the model of design was in eq. 6 as follow:

$$
\begin{array}{r}
Y=70.06+1.284 * X_{1}+2.329 * X_{2}-4.889 * X_{3}-10.054 * X_{4}+ \\
0.1498 * X^{*} * X_{2}+1.038 * X_{1} * X_{3}-1.324 * X_{1}^{*} X_{4}+2.661 * X_{2} X_{3}- \\
1.535 * X_{2}^{*} X_{4}+0.72 * X_{3}^{*} X_{4}-0.419 * X_{1}^{2}-3.439 * X_{2}^{2}-1.148 * X_{3}^{2} \\
-4.616 * X_{4}^{2}
\end{array}
$$




\section{Optimum condition}

Equation (6) was used to determine the optimum condition of variables that give the higher percentage removal of dye. An experiment was then conducted on these variables to obtain the percentage of dye removal, and whether it is close to the value obtained from optimization. The result was as follows

$\mathrm{X} 1$ : eggshell $(\mathrm{g})=0.835$

X2: time (mint.) $=24$

$X 3$ : initial dye concentration $\mathrm{mg} / \mathrm{l}=10$

$\mathrm{X} 4: \mathrm{pH}=4.2$

The optimal values for dye removal, both expected and experimental (real), were $83 \%$ and $84.323 \%$, respectively; It shows that they are convergent values.
Effect of variables on dye removal:

Figure 1 shows the relation between the percentage of dye removal and the effective variables (amount of eggshell, contact time, initial concentration of $\mathrm{DB}$ and $\mathrm{pH}$ ). All these relationships were drawn together at the level of the 0 code for the variables values figure la shows that if the time increases the percentage of removal of dye increases to a certain extent and then starts to decrease slightly. On the other hand, the amount of egg shells has little effect on the removal of the dye.

The effect of increasing the initial concentration of the dye does not lead to an improvement in the percentage of dye removal as shown in figure $1 \mathrm{~b}$.

Figure 1c shows that increasing the $\mathrm{pH}$ reduces the dye removal, which reduces the absorbance of the dye. Therefore, the adsorption environment should preferably be acidic, not base, and the best $\mathrm{pH}$ values should be between 3 and 5 .

Table 3

RESULTS OF EXPERIMENT PLANNED ACCORDING TO CENTRAL COMPOSITE DESIGN

\begin{tabular}{|c|c|c|c|c|c|c|c|c|c|c|}
\hline \multirow[b]{2}{*}{$\begin{array}{l}\text { Exp. } \\
\text { No. }\end{array}$} & \multicolumn{4}{|c|}{ Coded Variables } & \multicolumn{4}{|c|}{ Real Variables } & \multicolumn{2}{|c|}{$\begin{array}{c}\text { Dye removal \% } \\
\mathbf{Y}\end{array}$} \\
\hline & $\mathrm{X}_{1}$ & $\mathbf{X}_{2}$ & $\mathrm{X}_{3}$ & $\mathbf{X}_{4}$ & $\begin{array}{c}\text { Egg } \\
\text { shell (g) }\end{array}$ & $\begin{array}{l}\text { Time } \\
(\min )\end{array}$ & $\begin{array}{c}\text { Dye con. } \\
\text { (mg/L) }\end{array}$ & $p \mathrm{H}$ & $\begin{array}{l}\text { Exp. } \\
\text { values }\end{array}$ & $\begin{array}{l}\text { Predicted } \\
\text { values }\end{array}$ \\
\hline 1 & -1 & -1 & -1 & -1 & 0.325 & 15 & 22.5 & 5 & 72.25 & 73.478 \\
\hline 2 & 1 & -1 & -1 & -1 & 0.775 & 15 & 22.5 & 5 & 75.82 & 76.318 \\
\hline 3 & -1 & 1 & -1 & -1 & 0.325 & 35 & 22.5 & 5 & 74.084 & 75.584 \\
\hline 4 & 1 & 1 & -1 & -1 & 0.775 & 35 & 22.5 & 5 & 79.89 & 79.023 \\
\hline 5 & -1 & -1 & 1 & -1 & 0.325 & 15 & 47.5 & 5 & 52.8 & 54.861 \\
\hline 6 & 1 & -1 & 1 & -1 & 0.775 & 15 & 47.5 & 5 & 59.77 & 61.852 \\
\hline 7 & -1 & 1 & 1 & -1 & 0.325 & 35 & 47.5 & 5 & 64.03 & 67.611 \\
\hline 8 & 1 & 1 & 1 & -1 & 0.775 & 35 & 47.5 & 5 & 70.5 & 75.201 \\
\hline 9 & -1 & -1 & -1 & 1 & 0.325 & 15 & 22.5 & 9 & 63.5 & 57.648 \\
\hline 10 & 1 & -1 & -1 & 1 & 0.775 & 15 & 22.5 & 9 & 56.67 & 55.194 \\
\hline 11 & -1 & 1 & -1 & 1 & 0.325 & 35 & 22.5 & 9 & 53.59 & 53.613 \\
\hline 12 & 1 & 1 & -1 & 1 & 0.775 & 35 & 22.5 & 9 & 54.97 & 51.758 \\
\hline 13 & -1 & -1 & 1 & 1 & 0.325 & 15 & 47.5 & 9 & 38.94 & 41.912 \\
\hline 14 & 1 & -1 & 1 & 1 & 0.775 & 15 & 47.5 & 9 & 46.26 & 43.609 \\
\hline 15 & -1 & 1 & 1 & 1 & 0.325 & 35 & 47.5 & 9 & 50.17 & 48.521 \\
\hline 16 & 1 & 1 & 1 & 1 & 0.775 & 35 & 47.5 & 9 & 49.94 & 50.817 \\
\hline 17 & -2 & 0 & 0 & 0 & 0.1 & 25 & 35 & 7 & 67.27 & 65.815 \\
\hline 18 & 2 & 0 & 0 & 0 & 1 & 25 & 35 & 7 & 70.45 & 70.951 \\
\hline 19 & 0 & -2 & 0 & 0 & 0.55 & 5 & 35 & 7 & 50.6 & 51.646 \\
\hline 20 & 0 & 2 & 0 & 0 & 0.55 & 45 & 35 & 7 & 62.96 & 60.96 \\
\hline 21 & 0 & 0 & -2 & 0 & 0.55 & 25 & 10 & 7 & 70.69 & 75.246 \\
\hline 22 & 0 & 0 & 2 & 0 & 0.55 & 25 & 60 & 7 & 61.2 & 55.689 \\
\hline 23 & 0 & 0 & 0 & -2 & 0.55 & 25 & 35 & 3 & 78.62 & 71.705 \\
\hline 24 & 0 & 0 & 0 & 2 & 0.55 & 25 & 35 & 11 & 25.53 & 31.491 \\
\hline 25 & 0 & 0 & 0 & 0 & 0.55 & 25 & 35 & 7 & 69.71 & 70.06 \\
\hline 26 & 0 & 0 & 0 & 0 & 0.55 & 25 & 35 & 7 & 67.6 & 70.06 \\
\hline 27 & 0 & 0 & 0 & 0 & 0.55 & 25 & 35 & 7 & 69.5 & 70.06 \\
\hline 28 & 0 & 0 & 0 & 0 & 0.55 & 25 & 35 & 7 & 72.15 & 70.06 \\
\hline 29 & 0 & 0 & 0 & 0 & 0.55 & 25 & 35 & 7 & 71.16 & 70.06 \\
\hline 30 & 0 & 0 & 0 & 0 & 0.55 & 25 & 35 & 7 & 70.2 & 70.06 \\
\hline 31 & 0 & 0 & 0 & 0 & 0.55 & 25 & 35 & 7 & 70.1 & 70.06 \\
\hline
\end{tabular}




\begin{tabular}{|c|c|c|c|c|c|}
\hline \multicolumn{2}{|c|}{ Term } & Coef & SE Coef & F-value & P-value \\
\hline \multicolumn{2}{|c|}{ Constant } & 70.0600 & 1.5480 & 47.23 & 0.000 \\
\hline \multicolumn{2}{|c|}{ x1:amount Eggshell } & 1.2840 & 0.8360 & 2.36 & 0.144 \\
\hline \multicolumn{2}{|c|}{$\mathrm{x} 2:$ Time } & 2.3285 & 0.8360 & 7.76 & 0.013 \\
\hline \multicolumn{2}{|c|}{ x 3 : Dye concentration } & -4.8893 & 0.8360 & 34.20 & 0.000 \\
\hline \multicolumn{2}{|c|}{$\mathrm{x} 4: \mathrm{pH}$} & -10.0535 & 0.8360 & 144.61 & 0.000 \\
\hline \multicolumn{2}{|c|}{$\mathrm{x} 1 * \mathrm{x} 1$} & -0.4193 & 0.7659 & 0.30 & 0.592 \\
\hline \multicolumn{2}{|r|}{$x 2 * x 2$} & -3.4393 & 0.7659 & 20.16 & 0.000 \\
\hline \multicolumn{2}{|r|}{$x 33^{*} x 3$} & -1.1481 & 0.7659 & 2.25 & 0.153 \\
\hline \multicolumn{2}{|r|}{$x 4 * x 4$} & -4.6156 & 0.7659 & 36.32 & 0.000 \\
\hline \multicolumn{2}{|r|}{$\mathrm{x} 1 * \mathrm{x} 2$} & 0.1497 & 1.0239 & 0.02 & 0.886 \\
\hline \multicolumn{2}{|r|}{$x 1 * x 3$} & 1.0378 & 1.0239 & 1.03 & 0.326 \\
\hline \multicolumn{2}{|r|}{$\mathrm{x} 1{ }^{*} \mathrm{x} 4$} & -1.3235 & 1.0239 & 1.67 & 0.215 \\
\hline \multirow{2}{*}{\multicolumn{2}{|c|}{$\begin{array}{l}x 2 * x 3 \\
x 2 * x 4\end{array}$}} & 2.6610 & 1.0239 & 6.75 & 0.019 \\
\hline & & -1.5353 & 1.0239 & 2.25 & 0.153 \\
\hline \multicolumn{2}{|r|}{$x 3 * x 4$} & 0.7202 & 1.0239 & 0.49 & 0.492 \\
\hline \multicolumn{2}{|c|}{ STD. Deviation $=4.09569$} & \multicolumn{3}{|c|}{ Average error $\%=4.05118$} & PRESS $=1492.79$ \\
\hline $\mathrm{R}^{2}=94.05 \%$ & \multicolumn{2}{|c|}{$\mathrm{R}^{2}($ pred $)=66.91 \%$} & \multicolumn{2}{|c|}{$\mathrm{R}^{2}(\mathrm{adj})=88.85 \%$} & \\
\hline
\end{tabular}

Table 4

ANALYSIS OF VARIANCE FOR DYE REMOVAL, THE ANALYSISWASDONE USING CODED UNITS. ESTIMATED REGRESSION COEFFICIENTS FOR Y IN EQ. (5)
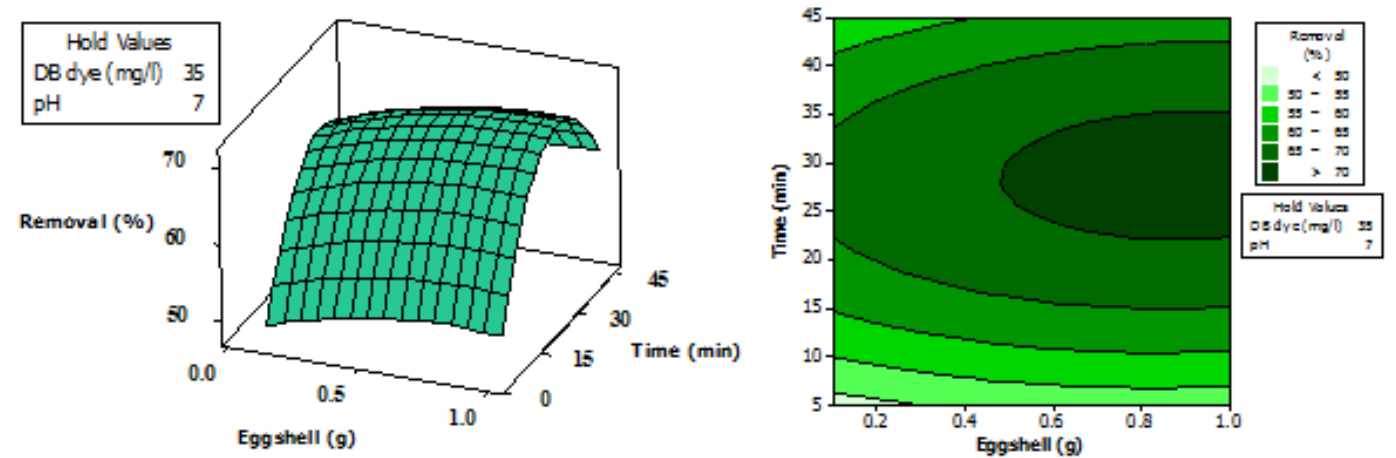

(a)
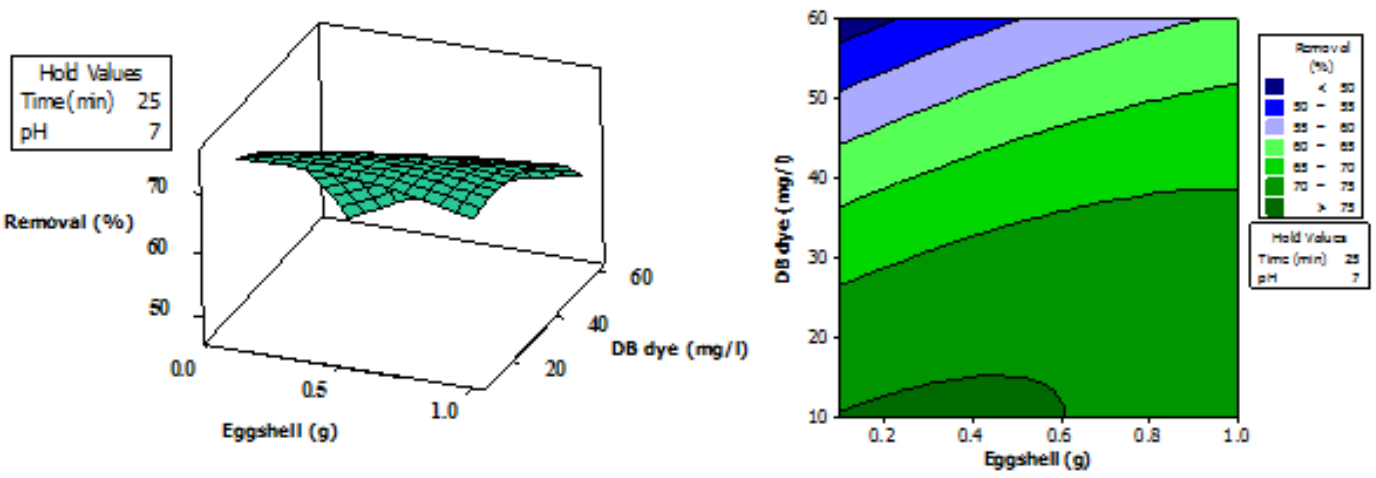

Fig.1. Response surface and contour plots for variables and its effect on DB dye removal efficiency (a) eggshell and time (b) eggshell and initial concentration of DB (c) eggshell and $\mathrm{pH}$

(b)
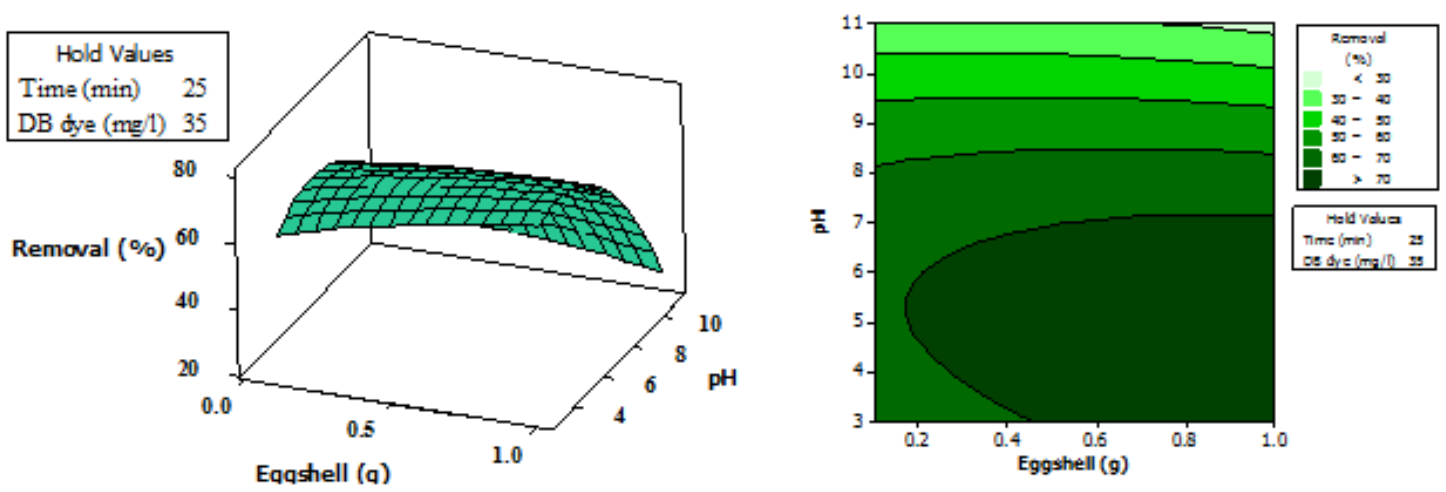

(c) 


\section{Adsorption isotherms modeling:}

The isothermal curves describe the relationship at the adsorption equilibrium between eggshell and dye solution at constant temperature. Several models were analyzed such as Langmuir , Freundlich, and Temkin isotherm. The constant parameters of the isotherm equations were calculated. These model equations are expressed as follow. [15].

Langmuir $\frac{\mathrm{C}_{\mathrm{e}}}{\mathrm{q}_{\mathrm{e}}}=\frac{\mathrm{C}_{\mathrm{e}}}{\mathrm{q}_{\max }}+\frac{1}{\mathrm{k}_{\mathrm{l}} \mathrm{q}_{\max }}$

Freundlich

$$
\mathrm{q}_{\mathrm{e}}=\mathrm{k}_{\mathrm{f}} \cdot \mathrm{C}_{\mathrm{e}}^{1 / \mathrm{n}}
$$

$$
\ln \mathrm{q}_{\mathrm{e}}=\ln \mathrm{k}_{\mathrm{f}}+1 / \mathrm{n} \ln \mathrm{C}_{\mathrm{e}}
$$

Temkin

$$
\mathrm{q}_{\mathrm{e}}=\mathrm{A}+\mathrm{B} \ln \mathrm{C}_{\mathrm{e}}
$$

where $\mathrm{q}_{\mathrm{e}}(\mathrm{mg} / \mathrm{g})$ is the adsorption capacity of equilibrium, $\mathrm{q}_{\max }$ is the maximum adsorption capacity and $\mathrm{k}_{1}(\mathrm{~L} / \mathrm{mg})$ is a constant related to the adsorption energy. $C_{e}(\mathrm{mg} / \mathrm{L})$ is the concentration of DB solution at equilibrium. Both $\mathrm{k}_{\mathrm{f}}$ and $\mathrm{n}$ are Freundlich constants related to adsorption' capacity and adsorption intensity. A, and B are constants. Table (5) shows the analysis of equilibrium data of the three models; as comparison the Langmuir, Freundlich models gave the greatest fit to the experimental data than Temkin model with $R^{2}=0.9854,0.9856,0.9562$ respectively. The Langmuir adsorption model is based on the assumption that maximum adsorption corresponds to a saturated monolayer of solute molecules on the adsorbent surface, and is applied to homogeneous sorption.

Freundlich isotherm model are an empirical adsorption isotherm used for non-ideal sorption and involves heterogeneous sorption. In table 5 , value of $n>1$ that's means the adsorption of DB dye on eggshell is a favorable process [17].

The Temkin isotherm model assumes a uniform distribution of energies over of surface adsorption sites. [18].
Kinetic models and effect of contact time:

Figure 2 shows the amount of sorption of dye per gram of eggshell at any time of two different initial concentration $10,22.5 \mathrm{mg} / \mathrm{L}$ of DB dye, increasing at the beginning till reached equilibrium at $90 \mathrm{~min}$. for both concentration of dye. The increasing of initial concentration from 10 to 22.5 $\mathrm{mg} / \mathrm{L}$ will increase the uptake of DB dye on the eggshell due to surface adsorption which is increase with increasing the sorbate quantity [5].

Adsorption kinetics and effect of contact give information on the adsorption process mechanisms. In the present work two of the most widely used kinetic models which are pseudo-second order, intra-particle diffusion.

pseudo-second order model :

$$
\frac{\mathrm{t}}{\mathrm{q}_{\mathrm{t}}}=\frac{1}{\mathrm{k}_{2} \mathrm{qe}^{2}}+\frac{\mathrm{t}}{\mathrm{qe}_{\mathrm{e}}}
$$

where $q_{\text {and }}$ an are the adsorption capacity at equilibrium and at time $t$, respectively $(\mathrm{mg} / \mathrm{g}), \mathrm{k}_{2}$ is the rate constant of pseudo- second order adsorption ( $\mathrm{g} / \mathrm{mg} \cdot \mathrm{min}$ ).

$$
\mathrm{h}=\mathrm{k}_{2} \mathrm{qe}^{2}
$$

$\mathrm{h}$ : are the initial sorption rate $(\mathrm{mg} / \mathrm{g} \cdot \mathrm{min}$

Intraparticle diffusion model: $\quad \mathrm{q}_{\mathrm{t}}=\mathrm{k}_{\mathrm{t}} \mathrm{t}^{0.5}+\mathrm{C}$

$\mathrm{k}_{\mathrm{t}}$ : the intraparticle diffusion rate constant $\left(\mathrm{mg} / \mathrm{g} \cdot \mathrm{min}^{0.5}\right), \mathrm{C}$ : constant gives about the thickness of boundary layer . The results in figure 3 and table 6 shows that the pseudosecond order model have higher $\mathrm{R}^{2}$ values $(0.9999$ for $10 \mathrm{mg} / \mathrm{L})$ and $(0.9984$ for $50 \mathrm{mg} / \mathrm{L})$. This means the adsorption is controlled by chemisorption ]19[.

The experimental value of $q_{e}\left(q_{e \text { exp }}\right)$ Very close to value of calculated $\left(q_{\text {a }}\right)$ for both initial concentration, and increase from 0.588 to 1.329 as the initial concentration increase from 10 to $22.5 \mathrm{mg} / \mathrm{L}$ also $\mathrm{h}$ increase, but $\mathrm{k}_{2}$ decrease.

Intra-particle diffusion model have less $R^{2}$ values $(0.9138,0.8117)$ for both initial concentration $(10,22.5 \mathrm{mg} /$ $L$ ) respectively than pseudo-second order. $k_{t}$ and $C$ increase as the initial concentration increase this means; the greater is the boundary layer effect; when $\mathrm{C}$ not equal zero This gives an idea about the boundary layer thickness, i.e. the larger intercept; the greater is the boundary layer effect. The plot of q tversus $t \frac{1}{2}$ with zero intercept determines the rate of adsorption. In this case intra-particle diffusion is not the only rate limiting step.

Table 5

CHARACTERISTICS OF ADSORPTION ISOTHERMS AT $24 \mathrm{C}^{\circ}, \mathrm{pH}=5$, SORBENT (EGGSHELL) $=0.775 \mathrm{G}$

\begin{tabular}{|c|c|c|c|c|c|c|c|c|}
\hline \multicolumn{3}{|c|}{ Langmuir } & \multicolumn{3}{c|}{ Freundlich } & \multicolumn{3}{c|}{ Temkin } \\
\hline $\begin{array}{c}\mathrm{q}_{\max } \\
(\mathrm{mg} / \mathrm{g})\end{array}$ & $\mathrm{K}$ l (l/mg) & $\mathrm{R}^{2}$ & $\mathrm{k}_{\mathrm{f}}$ & $\mathrm{n}$ & $\mathrm{R}^{2}$ & $\mathrm{~A}$ & $\mathrm{~B}$ & $\mathrm{R}^{2}$ \\
\hline 3.879 & 0.179 & 0.9854 & 0.564 & 1.579 & 0.9856 & 0.7322 & 0.7328 & 0.9562 \\
\hline
\end{tabular}

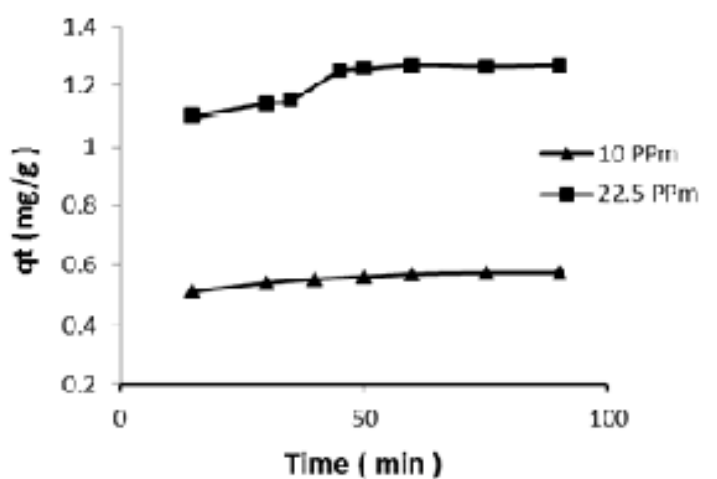

Fig. 2. Effect of contact time on removal and adsorption of DB dye 

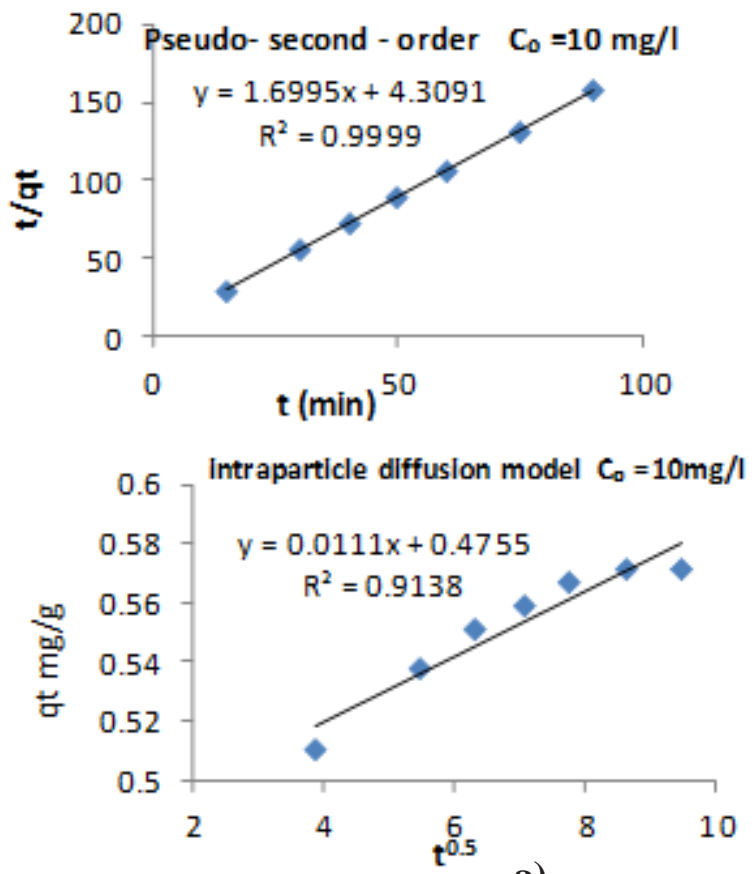

a)
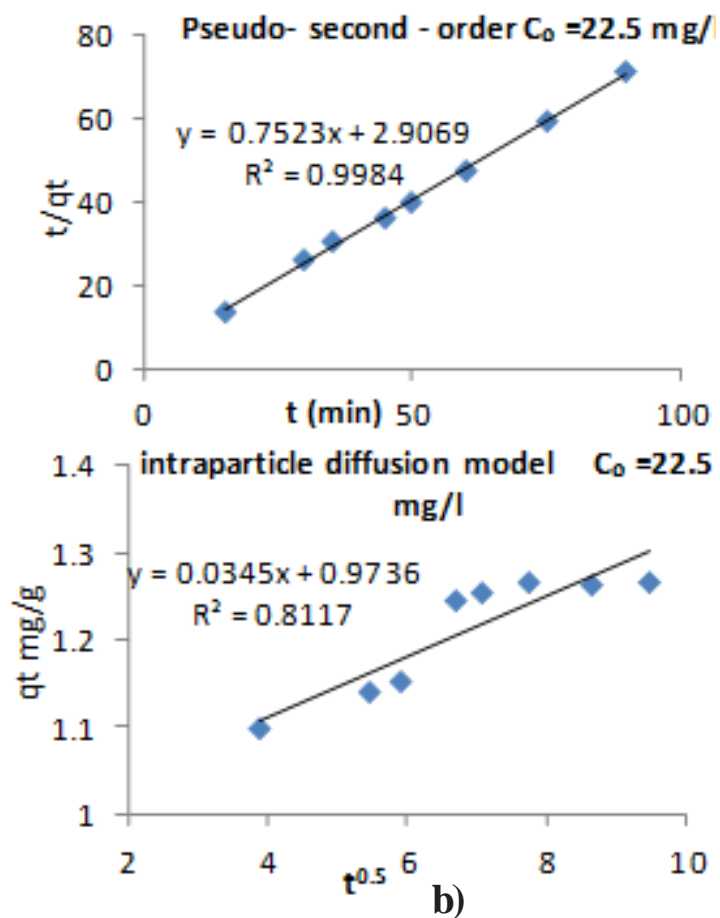

b)

Fig. 3. Contact time effect on DB dye adsorption by eggshell and kinetics plots (a) $10 \mathrm{mg} / \mathrm{L}$ and (b) $22.5 \mathrm{mg} / \mathrm{L}$

\begin{tabular}{|c|c|c|c|}
\hline \multirow{2}{*}{ Models } & Parameters & $\begin{array}{c}10 \\
\mathrm{mg} / \mathrm{L}\end{array}$ & $\begin{array}{c}22.5 \\
\mathrm{mg} / \mathrm{L}\end{array}$ \\
\cline { 2 - 4 } & qe exp $(\mathrm{mg} / \mathrm{g})$ & 0.571 & 1.266 \\
\hline \hline \multirow{4}{*}{ Pseudo -second order equation(11) } & $\mathrm{k}_{2}(\mathrm{~g} / \mathrm{mg} \cdot \mathrm{min})$ & 0.671 & 0.195 \\
\cline { 2 - 4 } & $\mathrm{qe}$ cal $(\mathrm{mg} / \mathrm{g})$ & 0.588 & 1.329 \\
\cline { 2 - 4 } & $\mathrm{h}(\mathrm{mg} / \mathrm{g} \cdot \mathrm{min})$ & 0.232 & 0.344 \\
\cline { 2 - 4 } & $\mathrm{R}^{2}$ & 0.9999 & 0.9984 \\
\hline \hline \multirow{2}{*}{$\begin{array}{c}\text { Intraparticle diffusion model } \\
\text { equation(14) }\end{array}$} & $\mathrm{k}_{\mathrm{s}}\left(\mathrm{mg} / \mathrm{g} \cdot \mathrm{min}^{0.5}\right)$ & 0.0111 & 0.0345 \\
\cline { 2 - 4 } & $\mathrm{C}(\mathrm{mg} / \mathrm{g})$ & 0.4755 & 0.9736 \\
\cline { 2 - 4 } & $\mathrm{R}^{2}$ & 0.9138 & 0.8117 \\
\hline
\end{tabular}

Table 6

KINETICS PARAMETERS FOR ADSORPTION OF DB DYE ONTO EGGSHELL POWDER

\section{Conclusions}

The eggshells could be used as a natural material, and low cost for the removal of DB dye from water and waste water effluent from textile factory. The optimum conditions are: amount of eggshell $0.835 \mathrm{~g}$, initial dye concentration $10 \mathrm{mg} / \mathrm{L}$, time $24 \mathrm{~min}, \mathrm{pH} 4.2$.

Langmuir and Freundlich model described the best fit with the data; the correlation coefficient $\mathrm{R}^{2}>0.98$. The process of adsorption of DB dye on eggshell fitted a Pseudo -second order kinetic model, which means that the adsorption is controlled by chemosorption. The more effected variables on adsorption of DB dye are $\mathrm{pH}$ and initial dye concentration, when $\mathrm{pH}$ acidic and less concentration gives better removal of dye.

\section{References}

1. GULANZ, 0., ARIKAN, B., 13, no. 7, 2004, p. 108.

2. TSAI, W.T., HSIEH, M.F., J. Chemosphere, 12, no. 4, 2001, p. 45.

3. KAREEM, H., AL-HUSSIEN, E. A., J. Baghdad for Sci., 9, 2012, p. 680.

4. FAHMI, C.Z.A., ABIDIN, N., RAHMAT, R., J. of Environ. Sci. and Development, 1, no. 2, 2010, p. 193.

5. GEORGIOU, D., MELIDIS, P., AIVASIDIS, A., GIMOUHOPOULOS, K., Dyes and Pigments, 10, no. 52, 2002, p. 69.

6. ANSARI, R., DELAVAR, A.F., J. Appl. Polymer. Sci., 11, no. 3, 2009, p. 22.

7. MALIK, P.K., Dyes Pigments, 56, no. 10, 2003, p. 239.
8. DEMIRBAS, A., Journal of Hazardous Materials, 167, no. 1-3, 2009, p.1.

9. SIMONESCU, C.M., FERDES M., Polish Journal of Environmental Studies, 21, no. 6, 2012, p. 1831

10. PATESCU, R.E., SIMONESCU, C.M., ONOSE, C., BUSUIOC, T.L., PASARICA, D.E., DELEANU C., Rev. Chim. (Bucharest), 68, no. 1, 2017,p. 1.

11. BUSUIOC, L.T., SIMONESCU, C.M., PATESCU, R.-E., ONOSE, C., Rev. Chim. (Bucharest), 67, no. 12, 2016, p. 2504.

12. PATESCU, R.-E., BUSUIOC, T.L., NECHIFOR, G., SIMONESCU, C.M., DELEANU, C., U.P.B. Sci. Bull., Series B, 79, no. 1, 2017, p. 119.

13 .HUNGER, K., MISCHKE, P., RIEPER, W., RAUE, R., KUNDE, K., ENGEL, A., Azo Dyes, in Ullmann's Encyclopedia of Industrial Chemistry, Wiley-VCH, Weinheim, 2005.

14. BELTER, P.A., CUSSLER, E.L., Bio Separation Down Stream Processing For Biotechnology, New York, 1988, p. 145.

15. AKAZDAM, S., CHAFI, M., YASSINE, W., SEBBAHI, L., GOURICH, B., BARKA, N., J ournal of Materials and Environmental Sciences, 8, no. 3, 2017, p. 784.

16. COCHRON, W.G., COX, G.M., Experimental Design, John Wiley and Sons, New York, 1957.

17. HAMEED, B.H., MAHMOUD, D.K., AHMAD, A.L., J ournal of Hazardous Materials, 158, 2008, p. 65.

18. JENAN A. AL-NAJA , Removal of Dyes from Synthetic Wastewater by Agricultural waste, Iraqi Journal of Chemical and Petroleum Engineering, 18, no. 3, 2017, p. 31. 